УДК 636.2.082.4:57.086.13:591.463.11

(C) 2015

Ляшенко А. О., науковий співробітник

Черкаська дослідна станція біоресурсів НААНУ

\title{
КОРЕЛЯЦЙНА ЗАЛЕЖНІСТЬ МІЖ ЯКІСНИМИ ПОКАЗНИКАМИ СПЕРМИ БУГАЇВ ДОВГОТРИВАЛОГО ЗБЕРІГАННЯ
}

\section{Рецензент - кандидат сільськогосподарських наук Ю. М. Сотніченко}

\begin{abstract}
Проведено дослідження взаємозв'язку між фізіологічними, морфологічними і морфометричними характеристиками сперматозоїдів бугаїв різних порід Банку генетичних ресурсів залежно від термінів зберігання. Визначено вірогідний кореляційний зв'язок між показниками морфологї сперматозоїдів та морфологічними індексами. Встановлено зворотний зв'язок між вмістом патологічних форм і кількістю нормальних акросом: чим більша кількість сперматозоїдів з нормальною акросомою, тим менше аномальних клітин $r=-0,3$ ( $p<0,001)$. Існує негативний вірогідний корелячійний зв'язок між кількістю патологічних сперматозоїдів і HOST $(r=-0,54)(p<0,001)$, між відсотком пошкоджених акросом, кількістю патологічних і мертвих клітин та довжиною різних частин сперматозоїда $(r=-0,2)(p<0,05)$.
\end{abstract}

Ключові слова: кріоконсервована сперма, патологічні форми, акросома, морфометрія, кореляційний аналіз, довготривале зберігання.

Постановка проблеми. Збереження племінних ресурсів сільськогосподарських тварин полягає у створенні генофондових стад разом 3 кріоконсервацією та довготривалим зберіганням генетичного матеріалу в кріобанках [2].

Призначення кріобанку полягає у накопиченні та довгостроковому зберіганні генетичних ресурсів усіх видів сільськогосподарських тварин, а також у проведенні комплексу організаційних i технологічних заходів щодо збереження і раціонального використання наявного генофонду в Україні [1].

Згідно 3 програмою збереження генофонду порід необхідно проводити експертну оцінку генетичних ресурсів для встановлення доцільності їі подальшого зберігання та можливості використання в селекційному процесі [7].

Аналіз основних досліджень і публікацій, у яких започатковано розв'язання проблеми. Науковими дослідженнями деяких авторів встановлено, що показники рухливості, живучості та запліднювальної здатності глибоко замороженої сперми бугаїв, залишаються на високому рівні під час довготривалого зберігання.

У своїх дослідженнях автори звертали увагу на вивчення морфології, фізіології та морфомет- рії сперматозоїдів бугаїв, але мало зупинялися на взаємозалежності між даними показниками в умовах довготривалого зберігання [5, 8-10].

Важливо встановити зв'язок між різними показниками морфологіï, та визначити іï вплив на фізіологію і морфометрію сперматозоїдів.

Відомо, що морфологічні зміни можуть стосуватися всіх ділянок сперматозоїда.

Більшість морфологічних порушень сперматозоїдів пов'язані 3 розмірами певних частин сперматозоїда та, відповідно, можуть впливати на живучість і рухливість $[4,5,9]$.

У літературних джерелах $\epsilon$ інформація щодо впливу різних термінів зберігання на сперму бугаїв молочних і м'ясних порід $[3,4]$, але даних щодо взаємозв'язків між якісними характеристиками сперматозоїдів недостатньо, що й обумовлює актуальність наших досліджень та становить науковий і практичний інтерес.

Мета досліджень: встановити кореляційну залежність між якісними показниками сперми бугаїв довготривалого зберігання.

Завдання: провести оцінку фізіологічних, морфологічних i морфометричних показників сперми бугаїв молочних і м'ясних порід за різних термінів зберігання.

Матеріал і методика досліджень. У дослідженнях використовували кріоконсервовану сперму 160 бугаїв 22 порід м'ясного, молочного i комбінованого напрямків продуктивності.

Термін зберігання досліджуваних спермодоз становив від 10 до 45 років.

Нами було розділено сперму бугаїв на три групи: перша - 3 термінами зберігання 10-20 років, друга $-21-30$ і третя $-31-45$ років.

Дослідження фізіологічних, морфологічних i морфометричних характеристик сперматозоїдів бугаїв проводили за загальноприйнятою методикою в лабораторії Черкаського ПрАТ НВО «Прогрес» 3 використанням мікроскопа Olympus CX-31.

Підготовлені препарати сперматозоїдів аналізували за збільшення в 600-1500 разів згідно 3 ГОСТ 20909.3-75. 


\section{СІЛЬСЬКЕ ГОСПОДАРСТВО. ТВАРИННИЦТВО}

У процесі вивчення взаємозв'язків між якісними показниками сперми використовували кореляційний аналіз.

Одержані матеріали наукових досліджень обробляли методами математичної статистики за алгоритмами Плохинського Н. А. засобами програмного пакету «Statistica $-6.1 »$ у середовищі Windows на ПЕОМ [6].

Результати досліджень. За результатами досліджень нами було проведено кореляційний аналіз між різними фізіологічними і морфологічними показниками сперматозоїдів.

Пряма кореляційна залежність в дослідних зразках сперми довготривалого зберігання, встановлена між:

- прямолінійно-поступальним рухом (ППР) і виживаністю,

- активністю і кількістю сперматозоїдів 3 прямолінійно-поступальним рухом (Кппр),

- виживаністю і абсолютним показником живучості (АПВ),

- АПВ і тестом гіпоосмотичного набухання HOST (Hypo-osmotic Swelling Test),

- розміром сперматозоїда i прямолінійною швидкістю руху,

- прямолінійною швидкістю руху і HOST,

- відсотком мертвих сперматозоїдів і відсотком патологічних форм,

- АПВ і відсотком нормальних акросом,

- АПВ і відсотком живих сперматозоїдів та іншим (табл. 1, 2).

Визначено позитивний зв'язок між кількістю патологічних форм і відсотком пошкоджених акросом $(\mathrm{r}=0,3)(\mathrm{p}<0,05)$ та вірогідний негативний зв'язок між HOST і відсотком пошкоджених акросом $(\mathrm{r}=-0,44)(\mathrm{p}<0,001)$.

У спермі довготривалого зберігання виявилась така кореляційна залежність між АПВ і відсотком патологічних форм $(\mathrm{r}=-0,51)(\mathrm{p}<0,001)$, між кількістю патологічних сперматозоїдів і HOST $(\mathrm{r}=-0,54)(\mathrm{p}<0,001)$, між кількістю мертвих клітин i відсотком пошкоджених акросом $(\mathrm{r}=0,51)$ $(\mathrm{p}<0,01)$ та між АПВ і відсотком пошкоджених акросом $(\mathrm{r}=-0,49)(\mathrm{p}<0,001)$ (табл. 1).

Встановлена закономірність стосовно вмісту патологічних форм і кількості нормальних акросом: чим більша кількість сперматозоїдів 3 нормальною акросомою, тим менше аномальних клітин $\mathrm{r}=-0,3$ $(\mathrm{p}<0,001)$.

Обернена кореляційна залежність у дослідних зразках сперми різного терміну зберігання була встановлена між відсотком пошкоджених акросом, відсотком патологічних форм і кількістю мертвих клітин та розміром сперматозоїдів $(\mathrm{r}=-0,12-0,32)$ $(\mathrm{p}<0,05)$ (табл. 1).

Проведено кореляційний аналіз між показниками морфології сперматозоїдів та морфологічними індексами.

Визначено вірогідний кореляційний зв'язок між відсотком патологічних форм і індексом дефектності сперматозоїдів - r=0,91 ( $<<0,001)$, індексом патології і відсотком патологічних форм - r=0,97 ( $<0,001)$, відсотком патологічних форм i індексом тератозооспермії $-\mathrm{r}=0,61(\mathrm{p}<0,001)$.

В результаті досліджень нами було встановлено, що коефіцієнт кореляції між живучістю і відсотком патологічних форм мав негативне значення середньої сили $\mathrm{r}=-0,45(\mathrm{p}<0,05)$.

Разом 3 тим, коефіцієнт кореляції між відсотком патологічних форм і прямолінійною швидкістю руху був негативним середньої сили $\mathrm{r}=-0,3$ $(\mathrm{p}<0,05)$ (табл. 1).

Висока кореляційна залежність у дослідних зразках сперми довготривалого зберігання спостерігалася між АПВ-ППР - r=0,88 ( $<<0,001)$, АПВ-відсотком живих сперматозоїдів - $\mathrm{r}=0,85$ $(\mathrm{p}<0,001)$, ППР-відсотком живих сперматозоїдів $\mathrm{r}=0,91 \quad(\mathrm{p}<0,001)$, ППР-Кппр - $\mathrm{r}=0,71 \quad(\mathrm{p}<0,001)$, HOST i ППР - r=0,81 ( $<00,001)$, АПВ i HOST $\mathrm{r}=0,71$ ( $<<0,001)$ (табл. 2).

Встановлено, що коефіцієнт кореляції між розміром сперматозоїда і прямолінійною швидкістю руху мав позитивне значення слабкої сили $\mathrm{r}=0,15$ $(\mathrm{p}<0,05)$.

Разом $з$ тим, коефіцієнт кореляції між HOST i прямолінійною швидкістю руху та загальною довжиною сперматозоїда і HOST був позитивним середньої сили $\mathrm{r}=0,21-0,31$ ( $<<0,05)$ (табл. 2).

Висновок. Упродовж довготривалого зберігання (10-45 років) сперми бугаїв спостерігалася тенденція до зниження фізіологічних (HOST, АПВ, відсоток живих сперматозоїдів, швидкість руху) та морфологічних показників (сума патологічних форм, відсоток нормальних акросом, але знаходяться в межах норми), що свідчить про їх взаємозалежність та важливість під час оцінки якості сперми.

За результатами досліджень встановлено, що між більшістю фізіологічних показників спостерігався переважно вірогідний позитивний зв'язок, а між фізіологічними показниками i морфологією сперми переважно негативний.

Визначено вірогідний зворотний зв'язок між вмістом патологічних форм і кількістю нормальних акросом: чим більша кількість сперматозоїдів 3 нормальною акросомою, тим менше аномальних клітин. 


\section{СІЛЬСЬКЕ ГОСПОДАРСТВО. ТВАРИННИЦТВО}

1. Коефіцієнти кореляції між фізіологічними показниками і морфологією сперми бугаӥв (п=170)

\begin{tabular}{|c|c|}
\hline Кореляційні ознаки & Коефіцієнт кореляції \\
\hline живучість - кількість мертвих сперматозоїдів & $-0,73 \pm 0,02 * *$ \\
\hline живучість - \% патологічних форм & $-0,45 \pm 0,04 *$ \\
\hline кількість мертвих сперматозоїдів - \% патологічних форм & $0,5 \pm 0,04 * * *$ \\
\hline ППР - \% патологічних форм & $-0,55 \pm 0,04 * * *$ \\
\hline АПВ - \% патологічних форм & $-0,51 \pm 0,04 * * *$ \\
\hline \% пошкоджених акросом - довжина головки сперматозоїда & $-0,29 \pm 0,04 * * *$ \\
\hline кількість мертвих клітин - довжина головки сперматозоїда & $-0,18 \pm 0,05 * * *$ \\
\hline кількість мертвих клітин - довжина хвоста сперматозоїда & $-0,12 \pm 0,05^{*}$ \\
\hline \% патологічних форм - загальна довжина сперматозоїда & $-0,12 \pm 0,05^{*}$ \\
\hline \% нормальних акросом - рухливість & $0,52 \pm 0,04 * * *$ \\
\hline \% патологічних форм - прямолінійна швидкість руху & $-0,3 \pm 0,05^{*}$ \\
\hline \% патологічних форм - HOST & $-0,54 \pm 0,04 * * *$ \\
\hline \% патологічних форм - \% пошкоджених акросом & $0,3 \pm 0,05 * * *$ \\
\hline \% патологічних форм - індекс тератозооспермії & $0,61 \pm 0,02 * * *$ \\
\hline \% патологічних форм - індекс патології & $0,97 \pm 0,01 * * *$ \\
\hline \% патологічних форм - індекс дефектності сперматозоїдів & $0,91 \pm 0,01 * * *$ \\
\hline HOST - \% пошкоджених акросом & $-0,44 \pm 0,04 * * *$ \\
\hline \% нормальних акросом - \% живих сперматозоїдів & $0,51 \pm 0,04 * *$ \\
\hline АПВ - \% пошкоджених акросом & $-0,49 \pm 0,04 * * *$ \\
\hline
\end{tabular}

Примітка: ${ }^{*} \mathrm{p}<0,05 ; * * \mathrm{p}<0,01 ; * * * \mathrm{p}<0,001$

2. Коефіціснти кореляції між деякими фізіологічними показниками сперми бугаїв (n=170)

\begin{tabular}{|c|c|}
\hline Кореляційні ознаки & Коефіцієнт кореляції \\
\hline АПВ - ППР & $0,88 \pm 0,03^{* * *}$ \\
\hline ППР - динамічні характеристики & $0,37 \pm 0,05^{* *}$ \\
\hline ППР - Кппр & $0,71 \pm 0,02^{* * *}$ \\
\hline АПВ - динамічні характеристики & $0,41 \pm 0,05^{*}$ \\
\hline АПВ - \% живих сперматозоїдів & $0,85 \pm 0,03^{* * *}$ \\
\hline ППР - \% живих сперматозоїдів & $0,96 \pm 0,03^{* * *}$ \\
\hline розмір сперматозоїда - прямолінійна швидкість руху & $0,15 \pm 0,05^{*}$ \\
\hline прямолінійна швидкість руху - НОST & $0,31 \pm 0,05^{*}$ \\
\hline НОSТ - ППР & $0,81 \pm 0,02^{* * *}$ \\
\hline загальна довжина сперматозоїда - живучість & $0,24 \pm 0,05^{*}$ \\
\hline загальна довжина сперматозоїда - НОST & $0,21 \pm 0,05^{*}$ \\
\hline загальна довжина сперматозоїда - АПВ & $0,26 \pm 0,05^{*}$ \\
\hline АПВ - НОSТ & $0,71 \pm 0,03^{* * *}$ \\
\hline
\end{tabular}

Примітка: ${ }^{*} \mathrm{p}<0,05 ; * * \mathrm{p}<0,01 ; * * * \mathrm{p}<0,001$

\section{БІБЛІОГРАФІЯ}

1. Буркат В. П. Банк генетичних ресурсів основа прискореного виведення нових та збереження локальних порід / В. П. Буркат, А. П. Кругляк // Біотехнологічні, селекційні та організаційні методи відтворення, зберігання і використання генофонду тварин : [зб. наук. пр. УААН. Нац. об-ня по плем. справі у тваринництві]. - К., 1997. - C. $173-175$.
2. Зубеиь М. В. Методологічні аспекти збереження генофонду сільськогосподарських тварин / М. В. Зубець, В. П. Буркат, Ю. Ф. Мельник ; наук. ред. І. В. Гузєв. - К. : Аграрна наука, 2007. - 120 с.

3. Ляшенко A. O. Вплив тривалого зберігання кріоконсервованої сперми бугаїв у рідкому азоті на показники якості сперматозоїдів / А. О. Ляшенко // Вісник Полтавської державної аграрної 


\section{СІЛЬСЬКЕ ГОСПОДАРСТВО. ТВАРИННИЦТВО}

академії. - 2013. - №2. - С. 162-164.

4. Ляменко А. О. Морфологічний аналіз сперми бугаїв довготривалого зберігання / А. О. Ляшенко // Вісник Полтавської державної аграрної академії. - 2014. - №1. - С. 130-133.

5. Осташко Ф. И. Глубокое замораживание и длительное хранение спермы производителей / Ф. И. Осташко. - К. : Урожай, 1978. - 256 с.

6. Плохинский Н. А. Руководство по биометрии для зоотехников / Н. А. Плохинский. - М. : Колос, $1969 .-256 \mathrm{c}$.

7. Програма збереження локальних та зникаючих порід сільськогосподарських тварин в Україні (згідно з вимогами ФАО). «Збереження генофонду». Інститут розведення і генетики тварин
НААН [Електронний ресурс]. - Чубинське, 2013. - 24 c. - Режим доступу : http://www.br. com.ua/referats/technologii/105089.htm.

8. Сіраџький Й. 3. Життєздатність сперматозоїдів від плідників різних молочних порід / Й. 3. Сірацький, О. В. Бойко, С. І. Федорович // Тваринництво України, 2010. - №3. - С. 12-16.

9. Clement F. Sperm morphology and fertility / F. Clement, Y. Ladonnet, M. Magistrini // Animal Reproduction Science. - 2001. - №68. - P. 362-363.

10. Johnson $W$. H. The significance to bull fertility of morphologically abnormal sperm / W. H. Johnson // Veterinary Clinics of North America: Food Animal Practice. - 1997. - №13. P. 255-270. 